Case Report

\title{
Longitudinally Extensive Transverse Myelitis with Intramedullary Metastasis of Small-Cell Lung Carcinoma: An Autopsy Case Report
}

\author{
Kenya Nishioka, ${ }^{1}$ Ryota Tanaka, ${ }^{1}$ Satoshi Tsutsumi, ${ }^{2}$ Hideki Shimura, ${ }^{3}$ Yutaka Oji, \\ Harumi Saeki, ${ }^{4}$ Yukimasa Yasumoto, ${ }^{2}$ Masanori Ito, ${ }^{2}$ Nobutaka Hattori, ${ }^{1}$ and Takao Urabe ${ }^{3}$ \\ ${ }^{1}$ Department of Neurology, Juntendo University School of Medicine, 2-1-1 Hongo, Bunkyo, Tokyo, Japan \\ ${ }^{2}$ Department of Neurosurgery, Juntendo University Urayasu Hospital, 2-1-1 Tomioka, Urayasu, Chiba, Japan \\ ${ }^{3}$ Department of Neurology, Juntendo University Urayasu Hospital, Chiba, Japan \\ ${ }^{4}$ Department of Pathology, Juntendo University Urayasu Hospital, 2-1-1 Tomioka, Urayasu, Chiba, Japan
}

Correspondence should be addressed to Kenya Nishioka; kenya.nishioka@gmail.com

Received 12 October 2013; Accepted 28 November 2013

Academic Editors: A. Amirjamshidi, F. C. Henderson, N. S. Litofsky, M. Moonis, and J. B. White

Copyright (c) 2013 Kenya Nishioka et al. This is an open access article distributed under the Creative Commons Attribution License, which permits unrestricted use, distribution, and reproduction in any medium, provided the original work is properly cited.

\begin{abstract}
Background. Longitudinally extensive transverse myelitis (LETM) is characterized by spinal cord inflammation extending vertically through three or more vertebral segments. The widespread use of MRI revealed LETM more frequency than ever. We report the case of a patient with pathologically confirmed small-cell lung carcinoma metastasis into the spinal cord presenting as LETM. Case Presentation. A 74-year-old man developed rapidly progressive sensorimotor disturbance and vesicorectal dysfunction. T2weighted magnetic resonance imaging of the spine revealed LETM at the level of from T3 to conus medullaris; gadolinium enhancement showed concurrent tumor in the thoracic spinal cord from T10 to T11. Systemic survey identified a nodular mass in the lung that was verified as small-cell carcinoma. Following initial failed treatment by high-dose steroid, the patient underwent an emergent microsurgical tumor resection. Histological examination was identical with the lung carcinoma. The patient died of tumor progression at the 47th day after admission. At autopsy, only changes of edema were found in the gray matter of the cord, while tumor cells were not noted in it. Conclusion. Metastasis may rarely present symptoms of LETM. Prompt identification of underlying etiology by contrast examination and systemic survey is crucial for the patient assumed as LETM.
\end{abstract}

\section{Introduction}

Longitudinally extensive transverse myelitis (LETM) is characterized by spinal cord inflammation extending vertically through three or more vertebral segments [1]. The widespread use of magnetic resonance imaging (MRI) has revealed small cell lung cancer (SCLC) to be associated with many primary pathologies, including inflammatory diseases (collagen disease, neuromyelitis optica, Sjögren's syndrome, systemic lupus erythematosus, neuro-Behçet's disease, and sarcoidosis); infectious diseases (human T-lymphotropic virus1-associated myelopathy, human immunodeficiency virus infection, and adverse reaction to influenza vaccination); and noninflammatory diseases (intramedullary spinal neoplasms, spinal cord infarction, and spinal dural arteriovenous fistula) [1-14]. LETM has a heterogeneous pathogenesis, but reported cases associated with malignant disorders were very rare (Table 1). Here, we report a case of LETM due to intramedullary metastasis of small-cell lung carcinoma (SCLC), with rapid progression of paraplegia and sensory disturbance of the lower limbs. This patient presented with LETM on whole-spine MRI; despite intensive treatment, he died 47 days after admission. An autopsy was performed to assess the pathological findings of LETM.

\section{Case Presentation}

A 74-year-old man, a habitual smoker, developed gait disturbance with exacerbation in the following 8 days. At the time of admission, he had difficulty in walking without assistance. His past medical history was unremarkable. On admission, 
TABLE 1: Clinical features of LETM reported previously within 3 years.

\begin{tabular}{|c|c|c|c|c|c|c|c|}
\hline Authors & Year & Age & Gender & $\begin{array}{l}\text { The extent of spinal } \\
\text { cord lesion on MRI } \\
\text { findings }\end{array}$ & Initial symptoms & Pathogenesis & Prognosis \\
\hline $\begin{array}{l}\text { Graham et al. } \\
{[14]}\end{array}$ & 2013 & 25 & Male & T3-L2 & Spastic paraparesis & $\begin{array}{l}\text { Neuro-Behçet's } \\
\text { disease }\end{array}$ & Improved \\
\hline $\begin{array}{l}\text { Huang et al. } \\
{[13]}\end{array}$ & 2013 & 39 & Male & $\begin{array}{l}\text { C3-conus } \\
\text { medullaris }\end{array}$ & $\begin{array}{l}\text { Motor and sensory } \\
\text { disturbance in lower } \\
\text { limbs }\end{array}$ & SLE & Not improved \\
\hline $\begin{array}{l}\text { Salazar et al. } \\
{[12]}\end{array}$ & 2013 & 46 & Male & Entire spinal cord & $\begin{array}{l}\text { Leg weakness, ataxia, } \\
\text { and paresthesia }\end{array}$ & $\mathrm{NMO} / \mathrm{HIV}$ & Improved \\
\hline $\begin{array}{l}\text { Coulter et al. } \\
{[11]}\end{array}$ & 2012 & 18 & Male & $\begin{array}{l}\text { T3-conus } \\
\text { medullaris }\end{array}$ & $\begin{array}{l}\text { Spastic paraplegia and } \\
\text { pyramidal weakness }\end{array}$ & $\begin{array}{l}\text { Neuro-Behçet's } \\
\text { disease }\end{array}$ & Improved \\
\hline $\begin{array}{l}\text { White et al. } \\
{[10]}\end{array}$ & 2012 & 18 & Male & $\begin{array}{l}\text { T3-conus } \\
\text { medullaris }\end{array}$ & $\begin{array}{l}\text { Numbness and flaccid } \\
\text { paralysis in lower limbs }\end{array}$ & SLE & Improved \\
\hline $\begin{array}{l}\text { Stanifer et al. } \\
{[9]}\end{array}$ & 2012 & 50 & Female & $\mathrm{C} 4-\mathrm{T} 4$ & $\begin{array}{l}\text { Motor and sensory } \\
\text { disturbance in all four } \\
\text { limbs }\end{array}$ & Sjögren's syndrome & Improved \\
\hline $\begin{array}{l}\text { Franciotta et } \\
\text { al. [8] }\end{array}$ & 2011 & 62 & Female & C6-T11 & $\begin{array}{l}\text { Right leg weakness and } \\
\text { numbness in lower limbs }\end{array}$ & NMO & Improved \\
\hline $\begin{array}{l}\text { Habek et al. } \\
\text { [7] }\end{array}$ & 2011 & 43 & Female & $\begin{array}{l}\text { Medulla oblongata } \\
\text { to C7 }\end{array}$ & Spastic tetraparesis & $\begin{array}{l}\text { NMO spectrum } \\
\text { disorder }\end{array}$ & Improved \\
\hline $\begin{array}{l}\text { Itami et al. } \\
{[6]}\end{array}$ & 2011 & 73 & Female & Entire spinal cord & Gait disturbance & $\begin{array}{l}\text { HTLV-1-associated } \\
\text { myelopathy }\end{array}$ & Improved \\
\hline $\begin{array}{l}\text { Kumar et al. } \\
{[5]}\end{array}$ & 2011 & 82 & Female & T3-T11 & $\begin{array}{l}\text { Lower limbs weakness } \\
\text { and numbness }\end{array}$ & $\begin{array}{l}\text { Intravascular } \\
\text { lymphoma }\end{array}$ & Died \\
\hline \multirow[b]{2}{*}{$\begin{array}{l}\text { Nightingale } \\
\text { et al. [4] }\end{array}$} & \multirow[b]{2}{*}{2011} & 78 & Male & C5-T10 & Bilateral leg weakness & NMO & Not improved \\
\hline & & 31 & Female & $\mathrm{C} 5-\mathrm{T} 4$ & $\begin{array}{l}\text { Bilateral leg weakness } \\
\text { and numbness }\end{array}$ & $\begin{array}{l}\text { NMO spectrum } \\
\text { disorder }\end{array}$ & Improved \\
\hline $\begin{array}{l}\text { Ohnaka et al. } \\
\text { [3] }\end{array}$ & 2010 & 34 & Male & $\begin{array}{l}\text { From T3 vertebral } \\
\text { body to conus } \\
\text { medullaris }\end{array}$ & Paraplegia in lower limbs & Lung cancer & $\begin{array}{l}\text { Symptoms } \\
\text { remained }\end{array}$ \\
\hline $\begin{array}{l}\text { Akkad et al. } \\
\text { [2] }\end{array}$ & 2010 & 27 & Female & $\begin{array}{l}\text { From the top of } \\
\text { cervical vertebrae } \\
\text { to thoracic cord }\end{array}$ & $\begin{array}{l}\text { Weakness and } \\
\text { paresthesias in lower } \\
\text { limbs }\end{array}$ & $\begin{array}{l}\text { Vaccination against } \\
\text { influenza vaccine }\end{array}$ & Improved \\
\hline
\end{tabular}

he was fully alert. Neurological examination revealed sensory deficits, predominantly of deep sensation, and sphincter dysfunction with constipation and urinary disturbance. Manual muscle tests of all limbs indicated no paralysis, but lower limbs exhibited mild spasticity. Patellar and Achilles tendon reflexes were bilaterally brisk. Vibratory sensation was bilaterally diminished below the anterior superior iliac spine, but temperature and pain modalities were preserved. All tested hematological and biochemical parameters were within normal, including thyroid function, serum immunoglobulin, and serum vitamin B12. The levels of anti-SSA and anti-SSB antibodies were below $7.0 \mathrm{U} / \mathrm{mL}$. Progastrin-releasing peptide level was elevated to $189 \mathrm{pg} / \mathrm{mL}$ (normal $<70 \mathrm{pg} / \mathrm{mL}$ ), and carcinoembryonic antigen level was also considerably high $(59.7 \mathrm{ng} / \mathrm{mL}$, normal <5.0 ng/mL). MRI revealed extensive intramedullary abnormal intensity from the upper thoracic cord down to conus medullaris. An intramedullary spinal cord tumor was detected at T10-T11 that was enhanced by gadolinium (Figure 1). Chest computed tomography (CT) scans revealed a small nodular lesion of $18 \times 21 \mathrm{~mm}$ with spicula in the right lung S1 and hilar lymph node swelling on the right side, verified as small-cell carcinoma from biopsy specimen. Abdominal CT scans with iopamidol did not detect metastasis to the liver, spleen, or kidney. The metastasis led to gait disturbance and other sensorimotor symptoms. Initially, the patient was treated with intravenous methylprednisolone at 1,000 mg/day for 3 days, followed by oral prednisolone at $50 \mathrm{mg} /$ day, which are not effective. Then he underwent an emergent microsurgical tumor resection at 9 days after admission. The mass obtained from surgical resection contained atypical cells with chromatin condensation that were synaptophysin/CD56 positive but chromogranin A negative (Figures 2(a)-2(c)). After the resection, lumbar MRI indicated improvement of LETM. Neurological functions continued to deteriorate, and the patient died of pulmonary hemorrhage 47 days after admission. Autopsy confirmed a $20 \mathrm{~mm}$ SCLC in the right upper lung with right hilar adenopathy. Spinal sections showed mild edematous changes associated with the infiltration of lymphocytes and plasma cells in the gray matter. However, there were no cancer cells in the spinal cord, even at the edges of sections from T10-L1. Histological examination of the whole brain revealed 


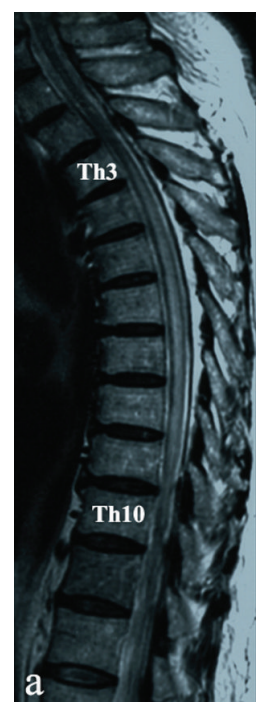

(a)

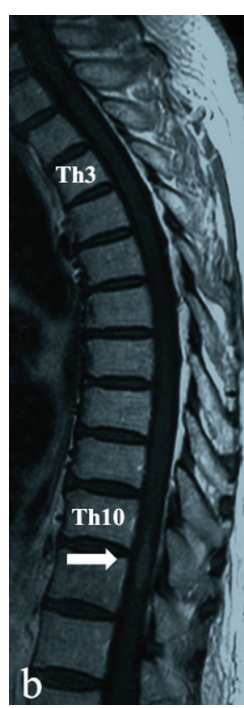

(b)

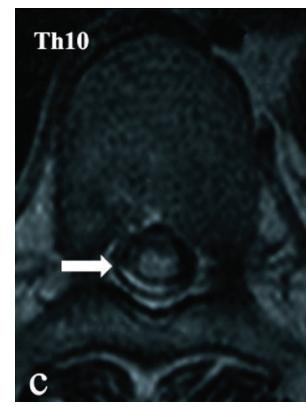

(c)

FIGURE 1: Thoracic magnetic resonance imaging reveals an intramedullary long spinal cord lesion from T3 to lower levels at 1 day after admission. (a) Sagittal T2-weighted image. (b) Gadolinium enhancement of the lesion at T10-T11. (c) Axial T2-weighted image at T10, revealing a high-intensity signal in the center of the spinal cord.

modest lymphocyte proliferation in the cortex and around the lateral ventricles but no sign of metastasis.

In contrast to LETM revealed by MRI and biopsy results indicating SCLC metastasis into the spine, postmortem pathology revealed only mild edematous changes localized around the dorsal horn. Furthermore, there were no signs of gray matter tumors or meningeal carcinomatosis and no pencil-shaped softening indicative of necrosis in autopsy spine samples.

\section{Discussion}

In our patient, metastasis of lung carcinoma to the spinal cord resulted in intramedullary spinal cord tumors and LETM. These tumors are observed in only $1 \%-2 \%$ patients with cancer at autopsy and in only $8.5 \%$ cases with central nervous system metastasis, most commonly from lung carcinoma [15]. LETM is detected on MRI more frequently than ever before. However, the precise mechanism underlying LETM development remains unknown. To our knowledge, it is very rare that LETM is caused by metastasis.

The pathological findings in the spinal cord of our patient indicate mild changes of edema without malignant cell invasion or metastasis. These findings suggest that LETMs themselves are reversible by ameliorating edema or temporary inflammation. Ohnaka et al. described that LETM was the result of lung carcinoma that completely disappeared after tumor resection [3]. They concluded that edema was the main pathology associated with LETM. In fact, many previous reports prove that LETMs due to inflammatory diseases can be ameliorated by medications (Table 1). Even intramedullary spinal cord metastases can be temporarily treated by tumor resection [3]. We speculate that gray matter is more sensitive to damage by venous congestion than white matter because of the difference in water distribution. This difference can lead to intramedullary LETMs. There were some discrepancies between clinical manifestations and spinal MRI findings in the case described here. These particular findings also confirm the slight differences in LETM.

Our patient developed paraplegia as the initial symptom. Intramedullary spinal cord metastases have a high frequency $(20 \%-40 \%)$ of neurological deficits as the first symptom before a diagnosis of cancer [15]. Kalayci et al. reported an average 52 days from neurological symptom onset to cancer diagnosis. Because this gap may result in cancer exacerbation, LETM should be considered as a critical sign of metastasis or primary tumors.

LETM can be caused by diverse spectrum of etiology; however, most of the patients presented in association with autoimmune disorders. (Table 1). We explored papers describing LETM appearing on MRI in PubMed in the past 3 years (Table 1). Many reports described discrepancies between the findings of MRI and clinical symptoms. Their initial symptoms were limited weakness and numbness in lower limbs, despite the broad emergence of LETM [2-14]. Despite mild changes in LETM, the prognosis in cases with metastasis is generally poor, with a 3-4-month mortality rate of approximately $80 \%$ [15]. These results depend on the stage of malignancy. Metastasis itself is associated with poor prognosis.

\section{Conclusions}

LETM may present as symptoms of intramedullary spinal cord metastasis. Cases complicated with primary malignant disorders are heralded by poor prognosis, but some may result in a significant symptom relief by surgical resection. 


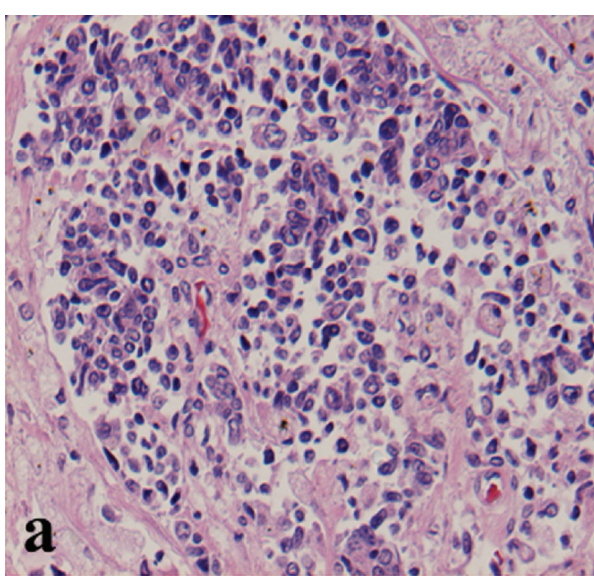

(a)

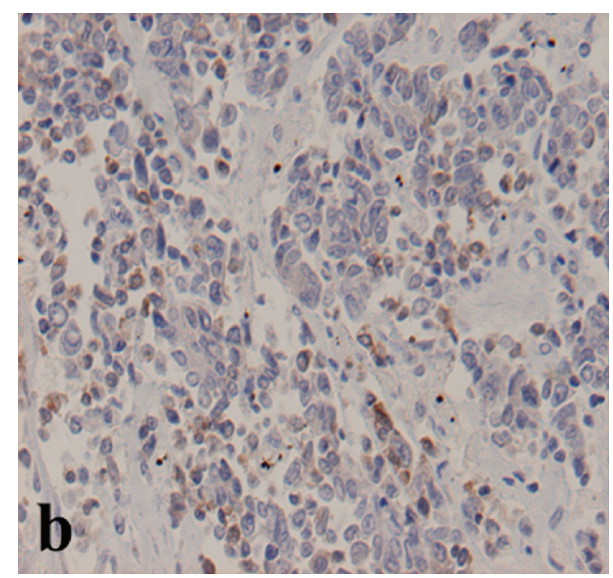

(b)

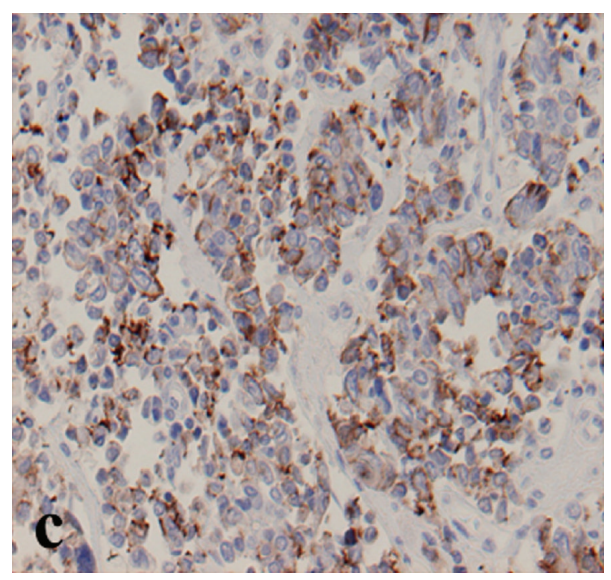

(c)

Figure 2: (a-c) Histopathology of the surgically resected spinal cord tumor, revealing a high nuclear/cytoplasmic ratio with necrosis. The sections were stained by hematoxylin and eosin (H\&E) (a) following immunostaining with synaptophysin (b) and CD56 antibodies (c). Both synaptophysin- and CD56-positive cells were observed. The tumor was attributed to small-cell lung carcinoma metastasis. Original magnification $\times 100$.

We emphasize that precise and rapid diagnosis of LETM is needed to optimize treatment success.

\section{Conflict of Interests}

The authors declare no financial or other conflict of interests.

\section{References}

[1] C. Trebst, P. Raab, E. V. Voss et al., "Longitudinal extensive transverse myelitis-it's not all neuromyelitis optica," Nature Reviews Neurology, vol. 7, no. 12, pp. 688-698, 2011.

[2] W. Akkad, B. Salem, J. W. Freeman, and M. K. Huntington, "Longitudinally extensive transverse myelitis following vaccination with nasal attenuated novel influenza $\mathrm{A}(\mathrm{H} 1 \mathrm{N1})$ vaccine," Archives of Neurology, vol. 67, no. 8, pp. 1018-1020, 2010.

[3] Y. Ohnaka, M. Nakajima, H. Katoh, H. Ichikawa, and M. Kawamura, "Intramedullary spinal cord metastasis presenting with acute onset longitudinally extensive spinal cord lesion," Rinsho Shinkeigaku, vol. 50, no. 10, pp. 725-727, 2010.
[4] H. Nightingale, J. Witherick, and A. Wilkins, "Diagnosis of longitudinally extensive transverse myelitis," BMJ Case Reports, 2011.

[5] N. Kumar, B. M. Keegan, F. J. Rodriguez, J. E. Hammack, and O. H. Kantarci, "Intravascular lymphoma presenting as a longitudinally-extensive myelitis: diagnostic challenges and etiologic clues," Journal of the Neurological Sciences, vol. 303, no. 1-2, pp. 146-149, 2011.

[6] R. Itami, N. Sanjo, H. Kuwahara et al., "Rapid progressive HTLV-1-associated myelopathy with bronchoalveolar lesions and a long spinal cord lesion extending to almost the entire spinal cord," Clinical Neurology, vol. 51, no. 2, pp. 130-134, 2011.

[7] M. Habek, I. Adamec, and V. V. Brinar, "Spinal cord tumor versus transverse myelitis," Spine Journal, vol. 11, no. 12, pp. 11431145, 2011.

[8] D. Franciotta, E. Zardini, R. Caporali et al., "Systemic sclerosis in aquaporin-4 antibody-positive longitudinally extensive transverse myelitis," Journal of the Neurological Sciences, vol. 303, no. 1-2, pp. 139-141, 2011.

[9] J. W. Stanifer, R. George, R. T. Keenan, and E. W. Massey, "What started this? Debilitating longitudinally-extensive myelitis," The American Journal of Medicine, vol. 125, pp. 1071-1073, 2012. 
[10] C. White, B. Leonard, and A. Patel, "Longitudinally extensive transverse myelitis: a catastrophic presentation of a flare-up of systemic lupus erythematosus," Canadian Medical Association Journal, vol. 184, no. 3, pp. E197-E200, 2012.

[11] I. Coulter, S. Huda, A. Baborie, and A. Jacob, "Longitudinally extensive transverse myelitis as the sole presentation of neuroBehçet's disease responding to infliximab," Journal of Spinal Cord Medicine, vol. 35, no. 2, pp. 122-124, 2012.

[12] R. Salazar, M. Cerghet, A. Shad, and N. P. Markowitz, "NMOIgG positive relapsing longitudinally extensive transverse myelitis (LETM) in a seropositive HIV patient," Clinical Neurology and Neurosurgery, vol. 115, pp. 1873-1875, 2013.

[13] L. K. Huang, C. C. Chung, B. Z. Chen, N. F. Chi, and C. J. Hu, "Systemic lupus erythematosus presented as extensive longitudinal myelitis," Acta Neurologica Taiwanica, vol. 22, pp. 67-71, 2013.

[14] D. Graham, A. McCarthy, E. Kavanagh, K. O’Rourke, and T. Lynch, "Teaching NeuroImages: longitudinally extensive transverse myelitis in neuro-Behcet disease," Neurology, vol. 80, pp. e189-e190, 2013.

[15] M. Kalayci, F. Çaǧavi, S. Gül, S. Yenidünya, B. Açikgöz, and T. Dóczi, "Intramedullary spinal cord metastases: diagnosis and treatment: an illustrated review," Acta Neurochirurgica, vol. 146, no. 12, pp. 1347-1354, 2004. 


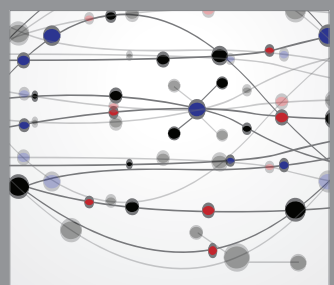

The Scientific World Journal
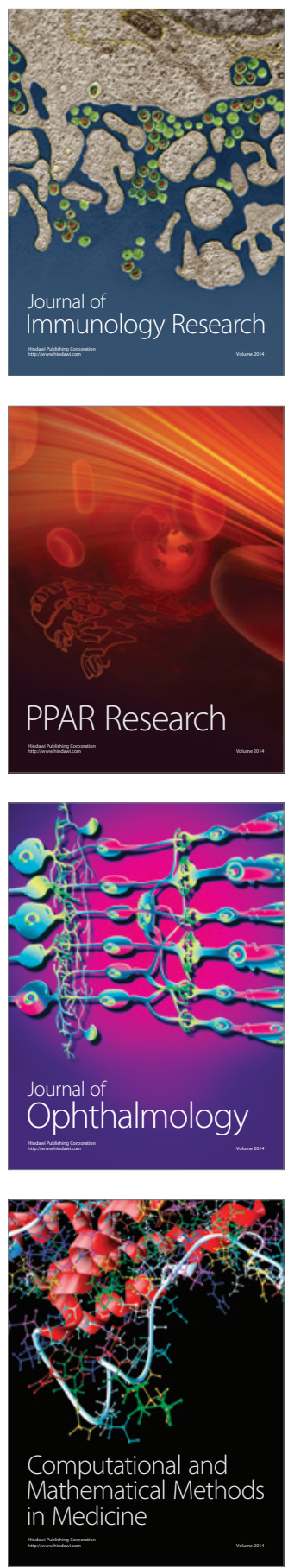

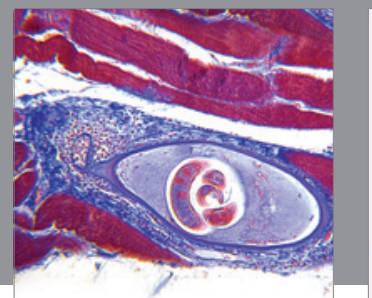

Gastroenterology

Research and Practice
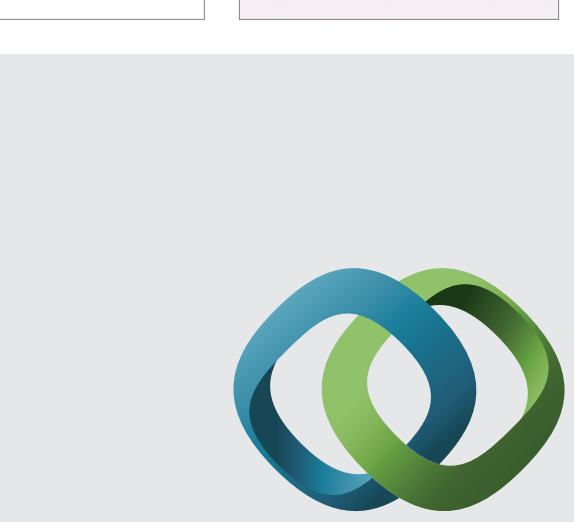

\section{Hindawi}

Submit your manuscripts at

http://www.hindawi.com
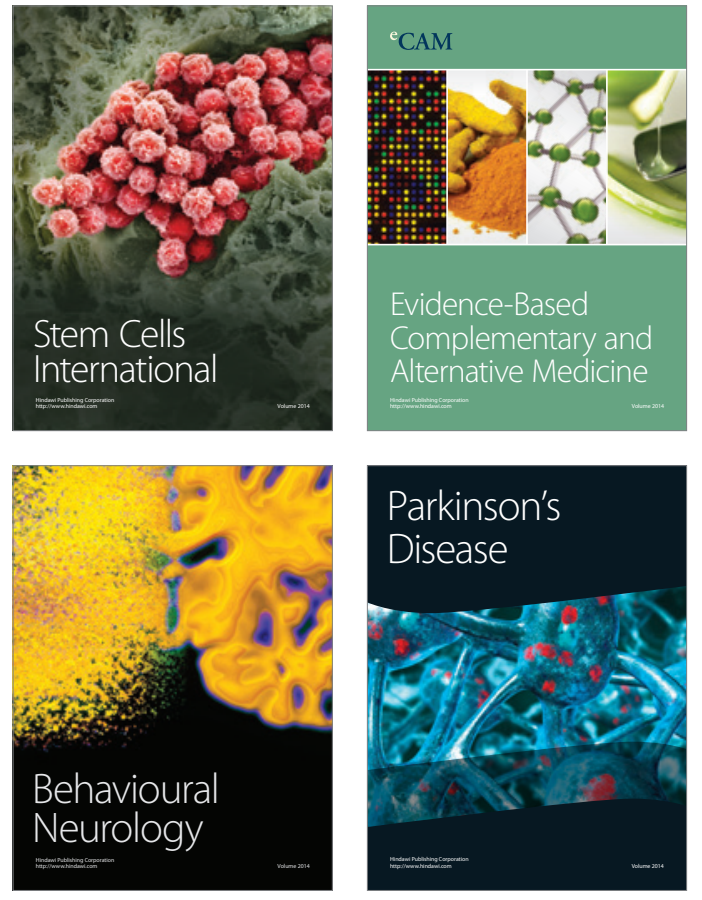
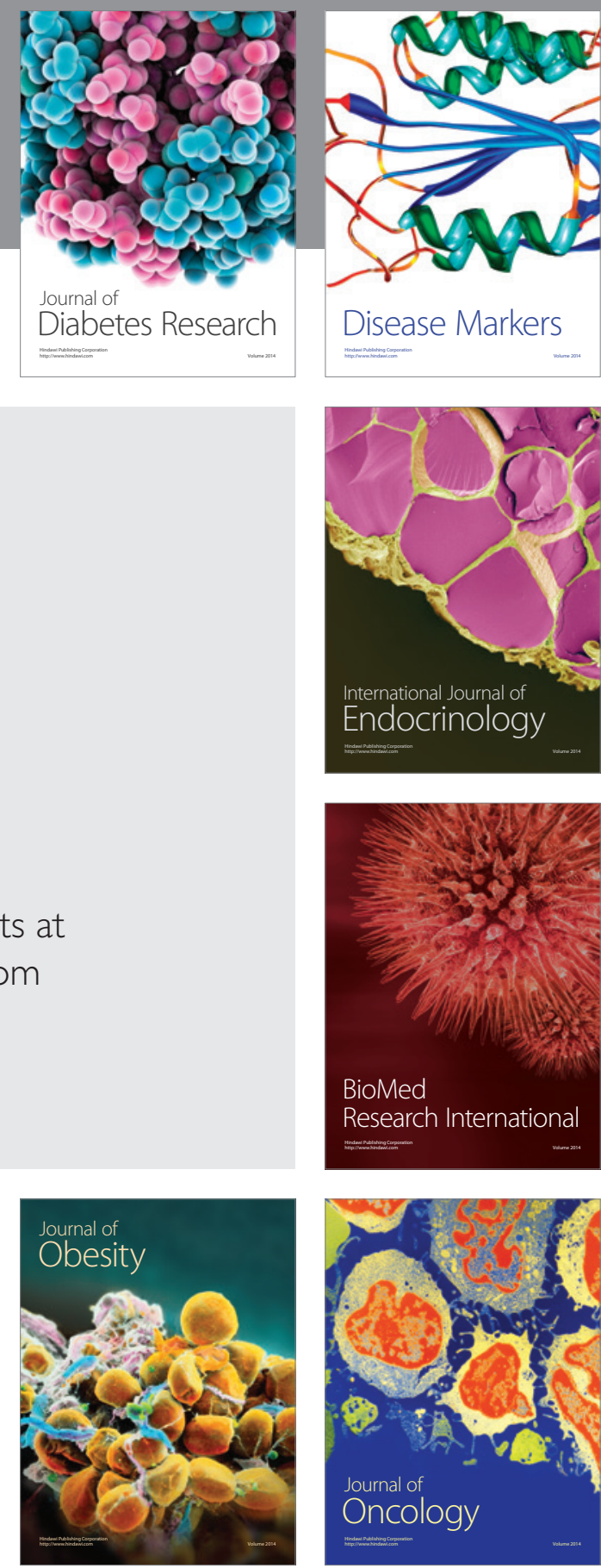

Disease Markers
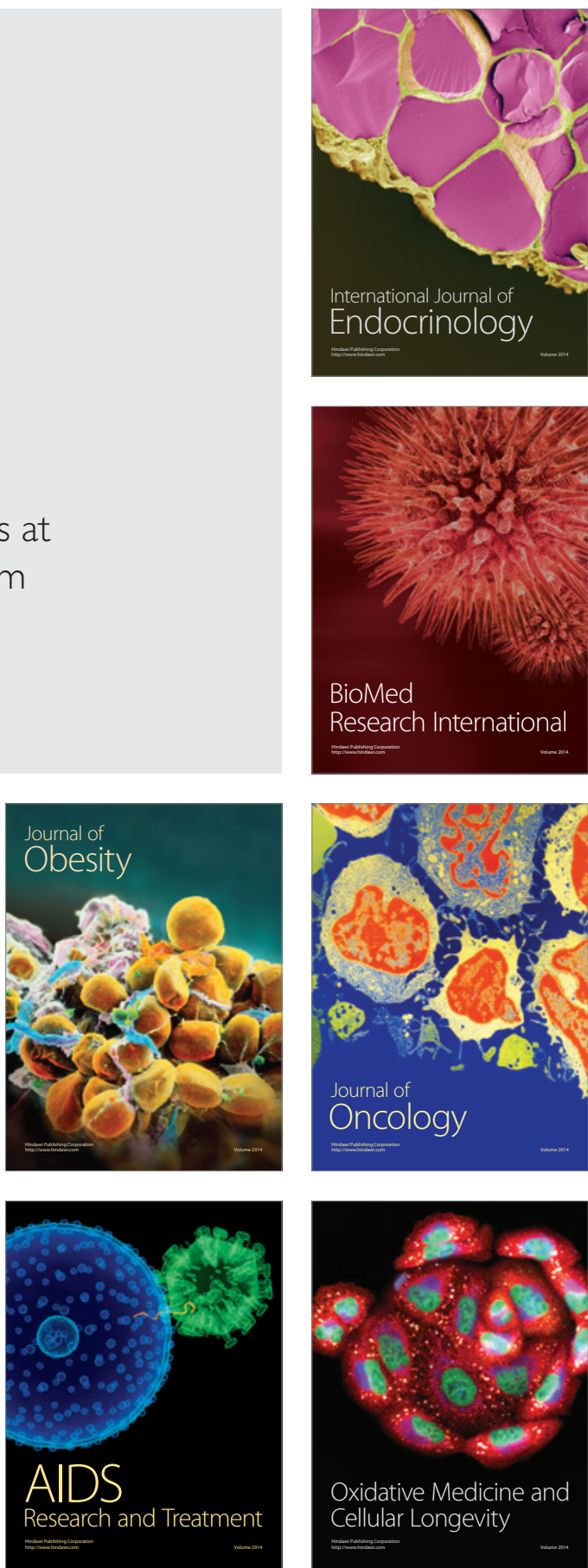